\title{
The Development of English Language Teaching Skills for Graduate Students through the Process of Learning by Doing
}

\author{
Wannakarn Likitrattanaporn ${ }^{1}$ \\ ${ }^{1}$ Faculty of Humanities, Srinakharinwirot University, Bangkok, Thailand \\ Correspondence: Wannakarn Likitrattanaporn, Faculty of Humanities, Srinakharinwirot University, Bangkok, \\ Thailand. Tel: 66-81-409-8208.E-mail: wannaka@g.swu.ac.th
}

Received: April 19, 2017 Accepted: June 1, 2017 Online Published: June 2, 2017

doi: 10.5539/elt.v10n7p96 URL: http://doi.org/10.5539/elt.v10n7p96

\begin{abstract}
The purposes of this investigation were 1) to examine the findings of effectiveness of the process of learning-by-doing 2) to develop students' skill of designing English teaching materials and teaching English language; and 3) to determine an efficient format of learning-by-doing used for training student-teachers in the skill of teaching English. The subjects of the study were 5 graduate students majoring in linguistics at Srinakharinwirot University in Bangkok, Thailand. This investigation employed qualitative research. The research instrument was a questionnaire designed to garner students' opinions towards learning of constructing English teaching materials and teaching English language. Qualitative data from group brainstorming were taken into account. The results showed that the students benefited from the process of learning-by-doing. It assisted them to discover knowledge of designing English teaching materials and English teaching skills by themselves. It was also determined that an efficient format for training student-teachers should include with group brainstorming at every step. This begins with the principles of the audio-lingual method, cognitive code learning theory and communicative language teaching approaches. Brainstorming was also conducted while adapting teaching materials, during practical teaching, self reflection and peer reflection.
\end{abstract}

Keywords: learning-by-doing, brainstorming, reflective technique, designing English teaching materials, English teaching skill

\section{Introduction}

\subsection{Introduce the Problem}

Educators, teachers, parents and students in Thailand realize that the English language is very important as a crucial tool for communication worldwide and as an international language in the ASEAN community. However, the Thai education system, particularly in teaching and learning English, remains problematic. One of the problems is continued emphasis of rote practice. Thai students are still required to memorize English vocabulary and practice rote grammar exercises. They are given very little opportunity to think critically and to use English for communication. The Prime Minister of Thailand has revealed reform of Thai education in many areas such as improving the quality of learners, reducing educational disparities, raising the standard of education, developing teachers and preparing for the ASEAN community. (Education Reform for Thailand's future, Education Policy of Prime Minister General Prayut Chan-Ocha, aired on television from June 6, 2014 to May 22, 2015)

As an instructor at Srinakharinwirot University in Bangkok, Thailand, the researcher is interested in preparing student-teachers to be effective English teachers who understand teaching theories and adapt them into an efficient pedagogy in the classroom. One of the researcher's responsibilities is teaching a course named "Methods of Second Language Teaching" for graduate students majoring in linguistics. The main objectives of this course are leading the students to comprehend the principles and teaching techniques of 3 teaching methodologies: audio-lingual method (ALM), cognitive code learning theory (CCLT) and communicative language teaching (CLT). Students are required to construct teaching materials based on these methodologies and to experiment with their own teaching materials in the classroom. The researcher believes that the students should learn by doing. Constructing teaching materials and practical teaching in the classroom can encourage 
student-teachers to develop themselves into effective English teachers. Faga (2016) states that successful student teaching experiences are the key factor in developing future teachers, increasing student success, and keeping effective teachers in the classroom.

\section{Review of Related Literature}

This investigation emphasizes the principles of learning-by-doing. Students are encouraged to understand the theories of ALM, CCLT and CLT and to apply the theories by constructing teaching materials and using them in the classroom. This review focuses on 4 main topics: learning-by-doing, reflective technique, brainstorming in group discussion, and summary of language teaching methodologies of ALM, CCLT and CLT.

\subsection{Learning by Doing}

Learning-by-doing was first formalized by the American educational philosopher John Dewey. Dewey taught that experience was an essential component of the educational process. Learning-by-doing can be referred to as experiential learning, learning through action, or learning through discovery and exploration. An article entitled "Experiential Learning", from Northern Illinois University, Faculty Development and Instructional Design Center (unknown year, p. 1) clearly identifies notable educational psychologists such as John Dewey (1859-1952), Carl Rogers (1902-1987) and David Kolb (b. 1939) who provided the groundwork of learning theories that focus on learning through experience or learning-by-doing. John Dewey instructed that learning through experience or learning-by-doing must focus on problem solving and critical thinking rather than memorization and rote learning. Rogers and Kolb defined learning-by-doing as cognitive learning or meaningful learning.

The definition of learning-by-doing comes from http://www.igi-global.com/dictionary/learning-by-doing/16832 refers to John Dewey and the representatives of progressive education who demonstrated that the keys to effective learning-by-doing were learning by thinking, reflecting on experience, revising, integrating, making new experiences, followed by reflecting, revising and integrating again. The author calls this a continuous cycle of experience and reflection.

\subsection{Reflective Technique}

The relationship between learning-by-doing and reflective technique comes from Dewey who stated that reliving an experience leads to making connections we do not learn from experience. (Dewey, 1933, as cited in Erasmus, 2012). Rhalmi (2011) states that reflective teaching is a kind of action research. It helps teachers become aware of what is happening in the classroom by identifying common problems, hypothesizing about possible causes and solutions, and applying an action plan. Rhalmi also explains that one of the advantages of the reflective technique is that it develops the quality of teaching through continuous improvement. The critical reflective data can be successfully implemented in the classroom. The concept of using the reflective technique in training student-teachers in this study is based on from Korthagen (2011, p.38) who explains that "this approach starts from concrete practical problems and the concerns of student-teachers in real contexts. It aims at systematic reflection by student-teachers. It builds on the personal interaction between the teacher educator and the student-teachers and on the interaction amongst the student-teachers themselves".

The underlying principles of learning-by-doing in this investigation are to discover knowledge through critical thinking, cognitive learning and meaningful learning rather than memorization and rote learning. The students are expected to learn by doing a task, discovering knowledge by themselves andy using cognition rather than memorizing. The reflective technique, stimulates students to evaluate what they have done, to review their positive and negative points, and to identify what should be improved to correct any mistakes.

\subsection{Brainstorming in Group Discussion}

Generally, brainstorming in group discussion is conducted in order to generate ideas to solve a problem. It is popularly used in classrooms whenever teachers want to elicit ideas or information from students or when they want students to help each other solve a problem. Nordquist (2016) clarifies the definition of brainstorming as an invention and discovery strategy in which a writer collaborates with others to explore topics, develop ideas, and/or propose solutions to a problem. Willis and Willis (2007) refer to Cullen in 1998 states that brainstorming has been found to be an extremely effective way of getting even shy learners involved in topics and promoting richer task interaction. From the researcher's experience brainstorming helps everyone feel that they have to work 
together to do something to solve their problems. It also helps when one member cannot create any ideas, others may help to find better ways to solve problems.

\subsection{Summary of the Theory and Teaching Techniques of ALM, CCLT and CLT}

The researcher has spent more than ten years studying the language teaching methodologies of ALM, CCLT and CLT from many well known educators such as Richards and Rodgers (1986), Brown (1994) and Larsen-Freeman (2007). The following is a brief summary of the main principles and teaching techniques of the language teaching methodologies. The students are trained to construct teaching materials and how to teach English language based on the principles and teaching techniques of these methodologies.

ALM was invented by the structural grammar linguists in the early twentieth century. This teaching method was influenced by the linguistic theory of structural grammar and the psychological theory of behaviorism. The main concepts from structural grammar are that language is a structural system including phonology, morphology and syntax. These concepts lead to emphasis on teaching dialogue, pronunciation, vocabulary and language sentence. Behaviorism focuses on stimulus and response with rewards and punishment. As a teaching methodology, this approach stimulates learners to form good habits through drills. Teaching dialogues from everyday language is introduced at an early stage. The technique used teaching dialogue is mimicry or dialogue memorization. After that, various techniques such as substitution drills are used for teaching vocabulary as well as expansion drills, transformation drills or repetition drills for creating sentences. Minimal pairs are popularly used for teaching pronunciation. The role of a teacher is as a model, whereas the student is an imitator who practices repeatedly.

Noam Chomsky pioneered the language acquisition device (LAD) of transformational generative grammar. He argues that a human being can produce one's own language to analyze language to gain what he calls "linguistic competence." His concept is similar to gestalt psychologists who define learning as an internalized system. As Boeree (2000) points out, gestalt theory is well known for its concept of insight learning. CCLT is built on these concepts. The format of this teaching method provides learners with a reading passage followed by various types of exercises such as "wh-questions," true/false, matching, multiple choice, gap filling etc. to check comprehension. The exercises are followed up with activities such as a dialogue, informal talk or discussions. After that the activities such as a dialogue, informal talk or discussion are provided.

Richards and Rodgers (1986, p. 65) mention that teaching English for communication got started in 1971 when D.A. Wilkins was asked by the Council of Europe to investigate how English is used for conveying the communicative meanings. Wilkins categorized English language into notional and communicative functions. Notional categories deals with concepts of time, quantity, space, case and deixis. Meanwhile, communicative functions include greeting, introducing, inviting, apologizing, suggesting and so on. Notional Syllabus and Functional Syllabus were introduced by Wilkins in 1976.

CLT starts from a theory of language as communication (Richards \& Rodgers: 1986, p.69). In the United States, sociolinguist Del Hymes elaborated the communicative principles. They are interaction, exchange ideas/information and context. These principles are also later called communicative competence, which is the goal of teaching CLT. It consists of linguistic or grammatical competence, sociolinguistic competence, discourse competence and pragmatic competence or strategic competence. Students are asked to produce language for communicating their ideas through communicative activities such as information gap, informal talk, role-play, discussion, writing essays etc.

\section{Research Methodology}

This investigation is action and qualitative research. This investigation is action and qualitative research. It was conducted in the researcher's classroom to train student-teachers to construct teaching materials and experiment them with their learners. The training took place in November 2016 at Somdet Prawannarat Kindergarten School, which is a primary school in Supanburi province, Thailand.

\subsection{Samples of the Study}

There were five graduate students in this study. Two students were in the Ph. D. program while three were in the M.A. program. One of the doctoral students was from Laos. He held a master degree majoring in educational linguistics. The second doctoral candidate completed her master degree majoring in Thai language. One of the master degree students completed his bachelor degree majoring in English language, one majored in Japanese 
language and one majored in Thai language. All five participants elected to experiment with their practical English language teaching at the primary school level.

\subsection{Research Instrument}

This investigation employed qualitative research. The research instrument was designed to determine students' opinions towards learning-by-doing in the process of creating teaching materials, reflecting on their own teaching experience and reviewing the practical teaching of their classmates. Additional research qualitative data was derived from group brainstorming.

\subsection{Procedures of the Study}

Step 1: Preparation

The researcher-teacher provided the students with knowledge of theories and teaching techniques of ALM, CCLT and CLT as well as the steps of teaching. How to adapt or create teaching materials was introduced. In this step, students were asked to investigate how to teach each method of English teaching from the related texts and video.

Step 2: Students' learning-by-doing

The students were asked to adapt their knowledge to construct teaching materials focusing on teaching techniques of ALM, CCLT and CLT. They also presented their teaching materials to the researcher and classmates. The students brainstormed good points and bad points, comments and suggestions to improve the materials. The improved materials were then given to native speakers of English in the department of linguistics at Srinakharinwirot University to check English accuracy. Finally, they experimented with their teaching at Somdet Prawannarat Kindergarten School. Each student-teacher taught two English classes which were 90 minutes per class. ALM was handled during the first class while CCLT and CLT were employed in the second class.

Step 3: Self and peer reflection

After each class, the teacher-students completed the research instrument to reflect on their teaching experience and to review the teaching of their classmates. Later, all of us discussed the good and bad points and offered suggestions for improving their teaching.

Step 4: Data were collected and analyzed

Step 5: Research was reported.

\section{Results of the Study}

\subsection{Students' Attitudes towards Learning-by-Doing}

The students were satisfied with the well-planned steps of learning-by-doing which began with theories and teaching techniques of ALM, CCLT and CLT through listening to lectures, watching videos, investigating by themselves and brainstorming in the group. They applied the knowledge they gained for constructing the teaching materials and experimented in the real classroom. One student pointed out that the process of learning-by-doing helped him understand how to improve his teaching materials. He explained that language teaching theories are necessary. The theories provided appropriate concepts of what to teach, how to teach, plus teaching techniques. He felt that knowing the teaching theories helped him adapt the materials to the actual level of the learners in the classroom. He also benefited from the presentation of teaching materials between him and his peers. Listening to various comments helped him understand how to improve his teaching materials. The other 4 students expressed how they felt more confident in constructing English teaching materials after group brainstorming.

\subsection{The advantages of Learning-by-Doing}

One student revealed that learning-by-doing helped her discover how to teach by herself. She was not satisfied with her initial teaching performance. She realized that the input in her teaching plan was higher than the 
learners' ability. She recognized that the learners had difficulties with the class. Most of them were unable to answer her questions. During the brainstorm after teaching, she felt that her misunderstanding could be checked and clarified. She also realized that she needed to improve her teaching materials for the next class to be more appropriate to learners' ability. The analytical comments and creative suggestions from the group discussion helped her improve her teaching approach. She also explained how listening to a lecturer by a specialist inspired her to investigate the task-based approach more thoroughly. This led her to realize that learner-centered activities should be used in the classroom. Her learners will be more active in participating with the teacher and their friends.

Learning-by-doing also helped another teacher-student realized that his teaching level was higher than the students' ability in his first class. He analyzed the students' potential and changed the input to be more suitable to the students' level for his second teaching session. This experience confirms that when we discover a problem we will find our own appropriate and effective way to solve it.

Moreover, learning-by-doing can help each student discover the good and weak points of each teaching methodology. ALM, CCLT and CLT were selected as the three teaching methodologies being observed in this research. The graduate students were trained to construct teaching materials based on the principles and teaching techniques of each methodology. They focused on teaching dialogue memorization, pronunciation, vocabulary and language structure in ALM; varieties of reading comprehension exercises in CCLT; and emphasizing interaction in pairs, exchanging information in small group work, plus asking learners to produce language by themselves through spoken or written language during the communicative activities. After teaching ALM, one of the students felt that ALM was really suitable for teaching pronunciation. The learners enjoyed practicing pronunciation. Using minimal pairs with repetition drills stimulated Thai learners at the primary level to pronounce final English consonants such as $/ \mathrm{t} / \mathrm{and} / \mathrm{d} / \mathrm{effectively.} \mathrm{This} \mathrm{student-teacher} \mathrm{also} \mathrm{realized} \mathrm{that} \mathrm{if}$ learners can pronounce nearly like native speakers of English, their potential will be very high.

All 5 teacher-students reported that ALM was used for teaching vocabulary and language structures efficiently. They employed substitution drills to teach vocabulary. They can also present additional types of sentences such as changing an affirmative sentence into a negative sentence using transformation drills. However, they reported that the young learners had difficulty with dialogue memorization. The learners could not memorize the entire dialogues and some needed more time to cope with the task.

One student- teacher discovered that his teaching should be student-centered more than teacher-centered while he experimented with CCLT that required the learners to comprehend a reading passage. He concluded that it would be useful if he encouraged the learners to comprehend the reading passage by themselves. All 5 teacher-students revealed that writing a short essay to communicate the learners' ideas was too difficult for most of the learners, even though it was perceived as a useful activity.

\section{Discussion of Findings}

\subsection{The Effectiveness of the Process of Learning-by-Doing}

5.1.1 Learning-by-doing can stimulate students to think and create their own teaching materials.

During informal interviews with the students, 4 of them said that it was the first time for them to produce English teaching materials. All 5 of them were proud that they were able to create teaching materials through their own practice and understanding. Benjamin Bloom, who created Bloom's Taxonomy in 1956, stated that higher thinking in education such as applying, analyzing, evaluating, or creating should be emphasized rather than just remembering facts or rote learning (Krathwohl, 2002). Reese (2011) confirms that learning-by-doing or learning from experiences results directly from one's own actions.

5.1.2 Learning-by-doing integrated with group brainstorming and feedback can help students to improve their teaching skills.

Brainstorming in a group discussion generated feedback on the students' teaching performances and what needed to be improved. All 5 students stated that comments from the researcher-teacher and classmates were very useful. They can use the comments to improve their teaching. This evidence confirms that critical feedback is one of the main elements in the process of learning-by-doing. This can help students gradually gain the skill of 
teaching. Nordquist (2016) explains that the purpose of brainstorming in a group discussion is to define a problem and determine a plan of action to solve it.

\subsection{The Opportunity for Students to Develop and Improve Their English Teaching Skill}

Learning-by-doing integrated with the reflective technique can assist students to improve their teaching. The students reported that self-reflection and peer reflection helped them improve their teaching more efficiently. Bartlett (1993) refers to Cruickshank and Applegate in 1981 who state that the reflective technique can stimulate teachers to think what happens in the classroom. It helps them to perceive alternative means of achieving goals and to consider the teaching event thoughtfully, analytically and objectively. Bartlett also explains that the reflective technique is the most important means for helping teachers to improve their practice. Similarly, Ord (2012) states that people learn best when they are personally involved in the learning experience. Knowledge has to be discovered by an individual if it is to have any significant meaning or make a difference in their behavior.

\subsection{The Efficient Format of Learning-by-Doing for Training Student-Teachers}

The researcher discovered that students benefit from three major components: learning-by-doing, group brainstorming and the reflective technique

Learning-by-doing encourages students to discover knowledge or skills by themselves. As Confucius, a Chinese teacher and philosopher revealed thousands of years ago, "I hear and I forget. I see and I remember. I do and I understand." (Kan, 2017)

Gebhard (1993) points out that student-teachers can develop their teaching when they have chances to talk about their real teaching issues. Brainstorming can provide students the opportunity to discuss what happened in their classroom. Hein (1991) refers to Vigotsky in 1978 proposes that knowledge can be constructed through interactions between people in relation to the world as well as through the distance between the actual developmental level as determined by independent problem solving and the level of potential development as determined by problem solving under adult guidance or in collaboration with more capable peers. The researcher agrees with the concept that more experienced people can help raise students to the level of their potential development.

Murphy (2001) mentions that teaching experience alone is insufficient as a basis for continuing teacher development. It is better if teachers have time to think or reflect on what they have done in the classroom. Reflection expands one's understanding of the teaching-learning process or it can also expand one's repertoire of strategic options as a language teacher.

Hence, three major components of learning-by-doing, brainstorming in a group discussion and the reflective technique should be taken into consideration if one wants a model of the efficient format of learning-by-doing for training student-teachers' skill of teaching English.

\section{Conclusions and Recommendations}

Learning-by-doing was used efficiently with 5 graduate students in this investigation. It helped the students discover the advantages and disadvantages of ALM, CCLT and CLT from their teaching experiences. Practical teaching in school also assisted them to comprehend the real problems in the classroom. They learned how to solve the problems such as adjusting the level of their teaching materials to suit the learners' ability. They are better equipped to ask learners more questions. If their learners cannot answer the questions, the student-teachers know that they have to explain more. These student-teachers also learned from their mistakes to improve their teaching.

The teaching techniques of brainstorming in a group discussion and the reflective technique are vital components in the cycle of learning-by-doing.

Learning-by-doing enhances students' learning and experience. It emphasizes a student-centered approach. The students are active throughout the learning process. Due to the process of social interaction in brainstorming, each student has an opportunity to reflect on her/his construction of teaching materials or experimentation with practical teaching. As a result, each student gradually discovers personal knowledge and experience. Furthermore, comments or suggestions from more experienced people can assist students to develop their teaching skills. 
Teachers/instructors should consider the cycle of vital components in the teaching and learning process. Instructors must prepare students to gain sufficient knowledge for the target task. It is also important to provide opportunities for students to perform tasks by themselves. The essential component of brainstorming activity for exchanging ideas, information, comments and suggestions should be taken into consideration. The reflective technique should be also used to stimulate students to express their opinions.

\section{Acknowledgements}

The author gratefully acknowledges the Faculty of Humanities, Srinakharinwirot University for supporting the research scholarship, the director and students at Somdet Prawannarat Kindergarten School as well as the five participating graduate students for their active learning and devotion as English teachers during their experimental teaching.

\section{References}

Bartlett, L. (1993). Second Language Teacher Education. In Richards Jack C. \& Nunan David (Eds.), Teacher development through reflective teaching (pp. 202-214). USA: Cambridge University Press.

Boeree, C. G. (2000). Gestalt Psychology. Retrieved from http://webspace.ship.edu/cgboer/gestalt.html

Brown, H. D. (1994). Teaching by Principles: An Interactive Approach to Language Pedagogy. New Jersey: Prentice Hall Regents.

Erasmus, C. J. (2012). Developing Reflective Practice Skills Through the Use of a Road Map. Journal of Family and Consumer Sciences Education. 30(2), Fall/Winter, 57-65.

Faga, K. K. (2016). Why Cannot Be Taught in a Classroom for Pre-Service Teachers: Cooperating Teachers Fill the Gap. Journal of Education and Human Development, March, 5(1), 176-181.

Gebhard, J. G. (1993). Second Language Teacher Education. In J. C. Richards, \& N. David (Eds.), Interaction in a teaching practicum (pp. 118-131). USA: Cambridge University Press.

Hein, G. E. (1991). Constructivist Learning Theory. Retrieved from https://www.exploratorium.edu/education/ifi/constructivist-learning

Kan, Q. (2017). What's your favourite Confucius quote on education and learning? Retrieved from $\mathrm{http} / / / \mathrm{www}$.open.edu/openlearn/education/12-famous-confucius-quotes-on-education-and-learning

Korthagen, F. A. J. (2011). Making Teacher Education Relevant for Practice: The Pedagogy of Realistic Teacher Education . Orbis Scholae, 5(2), 31-50.

Krathwohl, D. R. (2002). A Revision of Bloom's Taxonomy: An Overview. Theory into Practice, 41(3), 212-218. https://doi.org/10.1207/s15430421tip4104_2

Larsen-Freeman, D. (2007). Techniques and Principles in Language Teaching. United Kingdom: Oxford University Press.

Murphy, J. M. (2001). Reflective Teaching in ELT. In Celce-Murcia, Marianne (Ed.), Teaching English as a Second or Foreign Language. (pp. 499-514). USA: Heinle \& Heinle Thomson Learning.

Nordquist, R. (2016). Prewriting in composition. Retrieved from https://www.thoughtco.com/prewriting-composition-1691676

Northern Illinois University, Faculty Development and Instructional Design Center. (Unknown year). Experiential Learning. Retrieved from www.niu.edu/facdev/_pdf/guide/strategies/experiential_learning.pdf

Ord, J. (2012). John Dewey and Experiential Learning: Developing the theory of youth work. Journal: Youth \& Policy, 108, 55-72.

Reese, H. W. (2011). The Learning-by- Doing Principle. Behavioral Development Bulletin, 11, 1-19. https://doi.org/10.1037/h0100597

Rhalmi, M. (2011). Reflective teaching and action research. Retrieved from http://www.myenglishpages.com/blog/reflective-teaching-and-action-research

Richards, J., \& Rodgers, T. S. (1986). Approaches and Methods in Language Teaching. New York: Cambridge 
University Press.

Unknown author, (Unknown year). Education Reform for Thailand's future, Education Policy of the Prime Minister General Prayut Chan-Ocha, aired on television from June 6, 2014 to May 22, 2015, Retrieved from http://www.onec.go.th/onec_web/page.php?mod=Book\&file=view\&itemId=1451

Unknown author, (Unknown year). What is learning by doing? Retrieved from http://www.igi-global.com/dictionary/learning-by-doing/1683

Willis, D., \& Willis, J. (2007). Doing Task-based Teaching. United Kingdom: Oxford University Press.

\section{Copyrights}

Copyright for this article is retained by the author(s), with first publication rights granted to the journal.

This is an open-access article distributed under the terms and conditions of the Creative Commons Attribution license (http://creativecommons.org/licenses/by/4.0/). 